\title{
Multidrug Resistant Shigella Associated with Class 1 Integrase and Other Virulence Genes as a Cause of Diarrhea in Pediatric Patients
}

\author{
Samah Sabry El-Kazzaz ${ }^{1}$, Ghada El-Saeed Mashaly ${ }^{1 *}$, Mayada S. Zeid ${ }^{2}$ \\ ${ }^{1}$ Medical Microbiology and Immunology Department, Faculty of Medicine, Mansoura University, Mansoura, Egypt \\ ${ }^{2}$ Pediatrics Department, Faculty of Medicine, Mansoura University, Mansoura, Egypt \\ Email: ${ }^{*}$ ghadamashaly@yahoo.com
}

How to cite this paper: El-Kazzaz, S.S., Mashaly, G.E.-S. and Zeid, M.S. (2020) Multidrug Resistant Shigella Associated with Class 1 Integrase and Other Virulence Genes as a Cause of Diarrhea in Pediatric Patients. Open Journal of Medical Microbiology, 10, 1-16.

https://doi.org/10.4236/ojmm.2020.101001

Received: December 9, 2019

Accepted: January 3, 2020

Published: January 6, 2020

Copyright $\odot 2020$ by author(s) and Scientific Research Publishing Inc. This work is licensed under the Creative Commons Attribution International License (CC BY 4.0).

http://creativecommons.org/licenses/by/4.0/

\begin{abstract}
Background: Shigella is one of the most serious pathogens associated with bloody diarrhea in children. The empiric antibiotic therapy of enteric illness with blood streaked stool leads to emergence of multi drug resistant (MDR) Shigella. The condition gets exacerbated by presence of integrons that facilitate the horizontal spread. Virulence genes associated with MDR Shigella modulate the patient outcome, particularly in children. Objectives: The present study was aiming at isolation of MDR Shigella from children with diarrheal sickness and characterization of those isolates as regarding presence of class 1 integrase and other virulence genes. Methods: Four hundred and ninety patients under the age of five suffering from diarrheal illness were examined for presence of Shigella in their stool specimens. MDR Shigella was determined using the antibiotic susceptibility testing by disc diffusion method; those isolates were tested for presence of class 1 integrase by PCR. Multiplex PCR assay was used to determine the presence of virulence genes, virA, ial, sen, set1A, set $1 B$, sat, ipaBCD, $i p a H$ and st $x$ in the MDR Shigella isolates. Results: The isolation rate of Shigella from pediatric patients was $5.3 \%$. Most of the isolated Shigella (57.7\%) were from infants between 12 and 23 month. $73.1 \%$ of the identified Shigella were MDR. intI1 gene was present in $78.9 \%$ of MDR isolates. Muliplex PCR revealed that ipaH and ipaBCD, virA, sat, ial, set $1 A$ and $\operatorname{set} 1 B$, sen were detected in $94.7 \%, 78.9 \%, 73.7 \%, 68.4 \%, 42.1 \%$, $36.8 \%$ of the MDR Shigella isolates respectively. Conclusion: The MDR isolates represented a considerable percentage of Shigella detected in pediatric patients. Presence of intII gene in most of MDR Shigella reflects the higher possibility of resistant strains spread. Existence of a variety of virulence genes in those isolates is an important indicator of serious disease outcome.
\end{abstract}




\section{Keywords}

MDR, Shigella, Integrase, Diarrhea

\section{Introduction}

Shigella is one of the most important pathogens associated with a serious food born diarrheal disease termed shigellosis [1]. It accounted for about 5\% to $15 \%$ of diarrheal cases [2]. Human is the only reservoir of this bacterium that was found to be the cause of about 163 million cases of diarrhea in developing countries every year [3] and 1.1 million mortality per year all over the world [4], of which children under the age of ten years are mostly affected [5]. $61 \%$ of deaths caused by Shigella enteric illness are among pediatrics under the age of five [6].

Diarrhea streaked with blood in pediatrics is seriously considered as an important manifestation of enteric disease associated with invasion which usually leads to high morbidity and mortality outcomes; in developing countries, the commonest bacteria that mostly recovered from fecal samples of children suffering from blood streaked diarrhea are Shigella [7].

Beside the rehydration therapy, diarrheal diseases caused by Shigella usually require antibiotic administration to decrease the period of the disease and limit its spread among close associates; resistance to trimethoprim-sulfamethoxazole and ampicillin have been continuously emerged by Shigella isolates due to their excessive usage; ceftriaxone and flouroquinolones are suggested by the WHO for management of dysentery caused by Shigella in pediatric patients [8], and also they are efficient against Shigella isolates exhibiting multidrug resistance in immunosuppressed children [9]. Ceftriaxone is the antibiotic of choice for management of Shigella infection in localities at which resistance to flouroquinolones is frequent; however, azithromycin is suggested by the American Academy of Pediatrics as a substitutive therapy for dealing with Shigella dysentery specially caused by multidrug resistance isolates [10].

The most important predisposing factors that encourage Shigella species to be more resistant are the empirical therapy of blood streaked diarrhea as shigellosis, also the frequent antibiotic administration for such enteric diseases in spite being listed among causes of restricted suggestions of antimicrobial therapy as advised by the WHO [11].

Antimicrobial insensitivity in the enteric bacteria including Shigella is a serious problem as it records an elevated concern worldwide [12]. Shigella isolates also have the ability to gain resistant genetic determinant by horizontal spread and the situation becomes more aggravated by the appearance of multi drug resistant (MDR) Shigella species, particularly among patient suffering from diarrheal diseases [13].

Presence of genetic movable elements like transposons, insertion sequences (i.e integrons) and contagious plasmides is frequently linked to the multidrug 
resistance. The relation between integrons presence and the appearance of MDR isolates was initially documented in 1980s [14].

Functionally the integron consists of three components, intII gene which encodes the integrase enzyme that can recombine the genetic cassettes and change them to competent genes [15], attI that contains antimicrobial resistance genetic cassettes [14], and the $P_{c}$ promoter that controls the genetic cassettes transcription [16]. It has been documented that Shigella species exhibiting multidrug resistant criteria contain integrons of class 1 and class 2 [17].

Virulence factors of Shigella together with the patient immune response usually modulate the clinical presentation of shigellosis particularly in children. The disease spectrum is generally ranged from self limiting diarrhea which is usually mild, to severe diarrheal disease characterized by presence of blood and accompanied with fever and extra intestinal problems [13]. Intestinal cells invasion is the most important virulence character exhibited by Shigella isolates, it is modulated by ipaH, ipaA, ipaB, ipaC and ipaD genes carried by inv plasmid [18]. On the other hand, ial genes harbored by the same plasmid was found to be very important in cell to cell passage [19].

The chromosomal genes encoding Shigella enterotoxin $1(\operatorname{set} 1 A$ and $\operatorname{set} 1 B)$ are responsible for diarrhea in its watery phase. Enterotoxin 2 produced by Shigella species is encoded by sen gene and also carried by the invasion plasmid. The genus Shigella harbored also some members of class 1 serine protease autotransporters of Enterobacteriaceae as secreted autotransporter toxin (sat). Cell invasion and spread are also mediated by vir $A$ placed on virulent plasmids [20].

Shigella dysenteriae serotype 1 express $s t x-1$ and $s t x-2$ shiga toxins which are chromosomally encoded [21] and responsible for the harmful vascular injury to the central nervous system, kidney and colon [22] and this explain the life threatening complications of infection by this type of Shigella species [23].

Previous studies related to Shigella isolation in Egypt were performed mainly to study the epidemiology of this organism and to concern certain serotypes. The aims of the present study were to isolate MDR Shigella from stool specimens of children with diarrheal diseases attending outpatient clinics of Mansoura University Children Hospital (MUCH) and to characterize those isolates as regarding presence of class 1 integrase and other virulence genes being important determinants of Shigella resistance and disease severity particularly in children.

\section{Methods}

\section{The study plan:}

The research protocol was agreed by the Medical Institutional Review Board in Faculty of Medicine, Mansoura University with code number: R.19.10.655, informed consent for every one of the included patients was taken.

During the time period extending from February, 2017 to August, 2019, a cross sectional descriptive study was conducted on 490 children under the age of five attendening the outpatient clinics of $\mathrm{MUCH}$ and suffering from diarrheal 
illness. Twenty six Shigella species were isolated from those patients; then the MDR isolates were determined and evaluated for presence of class 1 integrase and other virulence genes.

\section{Patients' criteria and pathological samples:}

Stool specimens were collected from all studied cases fulfilling the inclusion criteria which were diarrhea with passage of stool in 24 hours for at least three times, being children under the age of five, not admitted at hospital and they had not received any antibiotic therapy. Stool samples were immediately transferred to the department of Medical Microbiology and Immunology at the Faculty of Medicine, Mansoura University where they were processed in the Microbiology Diagnostic and Infection Control Unit (MDICU).

\section{Sample processing and identification of Shigella isolates [24]:}

Stool samples were inoculated on tubes of selenite broth media which were incubated for 24 hours at $37^{\circ} \mathrm{C}$ for enrichment. Next day, subculture was done on Salmonella Shigella (SS) agar, Xylose Lysin Desoxycholate (XLD) agar and Hekton Enteric (HE) agar media, Shigella isolates appeared as non lactose fermenting colonies on the plates were selected for further identification by the standard biochemical reactions and the API 20E (Bio-merieux SA, Montalieu Vercica and France)

\section{Antibiotic susceptibility of Shigella isolates:}

The disk diffusion technique was used to assess the antibiotic sensitivity for all isolated Shigella according to the CLSI, 2014 [25]. MDR Shigella isolates were selected as being resistant to unrelated three or more classes of antimicrobials [26].

Detection of class 1 integrase and virulence genes in the MDR Shigella isolates:

All the MDR Shigella isolates were checked for presence of Class 1 integrase by PCR using the primer pair (fw 5'-ATGGCCGAGCAGATCCTGCACG-3' and rv 5'-GCCACTGCGCCGTTACCACCGC-3') for detection of 899 bp intI1 gene product with the following conditions: 5 minutes at $94^{\circ} \mathrm{C}$ for initial denaturation, then 35 cycles $\left(30\right.$ seconds at $94^{\circ} \mathrm{C}, 40$ seconds at $60^{\circ} \mathrm{C}$ and 1 minute at $72^{\circ} \mathrm{C}$ ). A step for final extension was achieved at $72^{\circ} \mathrm{C}$ for 7 minutes. the PCR was performed with a volume of $50 \mu \mathrm{L}$ reaction mixture including Taq DNA polymerase (1U), $100 \mathrm{ng} \mathrm{DNA}, 200 \mu \mathrm{M}$ dNTP, $1 \mu \mathrm{M}$ primers, $1.5 \mathrm{mM} \mathrm{MgCl}_{2}, 50$ $\mathrm{mM} \mathrm{KCl}, 10 \mathrm{mM}$ Tris-HCl (pH 8.3) [17].

Multiplex PCR assay was performed for all MDR Shigella isolates for detection of virulence genes including (virA, ial, sen, set1A, set1B, sat, ipaBCD, ipaH and st $x$ ) using primers listed in Table 1 . The test was conducted according to the previously described method [27] using $20 \mu \mathrm{L}$ volum of reaction mixture including $0.5 \mu \mathrm{L}(10 \mathrm{mM})$ deoxynucleotides, $0.5 \mu \mathrm{L}$ DNA template, $0.5 \mu \mathrm{L}$ primer of each examined gene, $0.5 \mu \mathrm{L}(50 \mathrm{mM}) \mathrm{MgCl}_{2}, 0.5 \mu \mathrm{L}(5 \mathrm{U} / \mu \mathrm{L})$ Taq DNA polymerase, $2.0 \mu \mathrm{L} 10 \times$ PCR buffer and $13 \mu \mathrm{L}$ distilled water $(2 \mu \mathrm{L}$ water was added In set $1 A /$ set $1 B)$. The amplification conditions of the multiplex PCR were initial 
Table 1. Primers used for detection of virulence genes by multiplex PCR.

\begin{tabular}{|c|c|c|c|c|}
\hline $\begin{array}{c}\text { The targeted } \\
\text { gene }\end{array}$ & Primer sequence & $\begin{array}{c}\text { Melting } \\
\text { temperature } \\
\left({ }^{\circ} \mathrm{C}\right)\end{array}$ & $\begin{array}{c}\text { band } \\
\text { Size, bp }\end{array}$ & Reference \\
\hline virA & $\begin{array}{l}\text { F-CTGCATTCTGGCAATCTCTTCACATC } \\
\text { R-TGATGAGCTAACTTCGTAAGCCCTCC }\end{array}$ & 58 & 215 & [28] \\
\hline ial & $\begin{array}{l}\text { F-CTGGATGGTATGGTGAGG } \\
\text { R-GGAGGCCAACAATTATTTCC }\end{array}$ & 58 & 320 & [28] \\
\hline sen & $\begin{array}{l}\text { F: 5'-ATGTGCCTGCTATTATTTAT-3' } \\
\text { R: 5'-CATAATAATAAGCGGTCAGC-3' }\end{array}$ & 60 & 799 & [28] \\
\hline $\operatorname{set} 1 A$ & $\begin{array}{l}\text { F: 5'-TCACGCTACCATCAAAGA-3' } \\
\text { R: 5'-TATCCCCCTTTGGTGGTA-3' }\end{array}$ & 55 & 309 & [28] \\
\hline $\operatorname{set} 1 B$ & $\begin{array}{l}\text { F: 5'-GTGAACCTGCTGCCGATATC-3' } \\
\text { R: 5'-ATTTGTGGATAAAAATGACG-3' }\end{array}$ & 55 & 147 & [28] \\
\hline sat & $\begin{array}{l}\text { F: 5'-ACTGGCGGACTCATGCTGT-3' } \\
\text { R: 5'-AACCCTGTAAGAAGACTGAGC-3' }\end{array}$ & 55 & 387 & [29] \\
\hline$i p a B C D$ & $\begin{array}{l}\text { F: 5'-GCTATAGCAGTGACATGG-3' } \\
\text { R: 5'-ACGAGTTCGAAGCACTC-3' }\end{array}$ & 60 & 612 & [30] \\
\hline$i p a H$ & $\begin{array}{l}\text { F: 5'-TGGAAAAACTCAGTGCCTCT-3' } \\
\text { R: 5'-CCAGTCCGTAAATTCATTCT-3' }\end{array}$ & 58 & 423 & [31] \\
\hline stx & $\begin{array}{l}\text { F: 5'-CAGTTAATGTGGTTGCGAAG-3' } \\
\text { R: 5'-CTGCTAATAGTTCTGCGCATC-3' }\end{array}$ & 60 & 895 & [28] \\
\hline
\end{tabular}

denaturation for 1 minute at $94^{\circ} \mathrm{C}$, then 35 cycles of denaturation for 1 minute at $94^{\circ} \mathrm{C}$, annealing for 90 seconds at $58^{\circ} \mathrm{C}$, extension for 1 minute at $72^{\circ} \mathrm{C}$ and final extension for 7 minutes at $72^{\circ} \mathrm{C}$.

\section{Statistical Analysis:}

Data analysis and processing were done using SPSS, version 21 software. Description of qualitative data was done using number and percent. Chi-square test was used to check the association between categorical variables, when expected cell count less than 5, Fischer exact test was used. For all statistical tests done the threshold of significance is fixed at $5 \%$. The results were considered to be significant when the error probability was less than $5 \%(\mathrm{p}<0.05)$.

\section{Results}

Twenty six Shigella isolates were detected in the examined 490 stool speciemns that were collected from patients under the age of five and suffering from diarrhea. The prevalence of Shigella among studied cases was found to be $5.3 \%$. Of the isolated 26 Shigella strains, $15(57.7 \%)$ were $S$. flexneri, 6 (23.1\%) were $S$. sonnei, 4 (15.4\%) were $S$. dysenteriae and 1 (3.8\%) was $S$. boydii.

Shigella isolation rate was found to be higher in patients under the age of two years, as $57.7 \%$ of the isolated Shigella were detected in infants between 12 and 23 month. There wasn't any statistically significant difference regarding distribution of Shigella isolates between males and females $(P=0.1)$. Throughout the study time, most of the isolated Shigella (69.2\%) were significantly detected in 
patients during warm climate, May till October (Table 2).

Clinical data of the studied patients revealed that, fever is the most common sign associated with Shigella infection as it was observed in $65.4 \%$ of patients showed culture positive results for Shigella with a statistically significant value ( $P$ $=0.04)$. Vomiting, bloody stool, dehydration were other common clinical features that were found to be related to Shigella infection as they were respectively recorded in $53.8 \%, 30.8 \%$ and $26.9 \%$ of Shigella infected patients (Table 3).

All of the isolated Shigella were sensitive to imipemem as revealed by the

Table 2. Demographic and environmental factors affecting patients infected with Shigella as a cause of diarrhea.

\begin{tabular}{|c|c|c|c|c|c|c|}
\hline & & \multicolumn{2}{|c|}{$\begin{array}{l}\text { Patients with diarrhea } \\
\text { positive results for } \\
\text { Shigella }(\mathrm{n}=26)\end{array}$} & \multicolumn{2}{|c|}{$\begin{array}{l}\text { Patients with diarrhea } \\
\text { negative results for } \\
\text { Shigella }(\mathrm{n}=464)\end{array}$} & \multirow[t]{2}{*}{$P$ value } \\
\hline & & No & $\%$ & No & $\%$ & \\
\hline \multirow[t]{3}{*}{$\begin{array}{c}\text { Age } \\
\text { (month) }\end{array}$} & $\begin{array}{l}0-11 \\
n=80\end{array}$ & 7 & 26.9 & 73 & 15.7 & \multirow{3}{*}{$0.02^{*}$} \\
\hline & $\begin{array}{l}12-23 \\
\mathrm{n}=175\end{array}$ & 15 & 57.7 & 160 & 34.5 & \\
\hline & $\begin{array}{l}24-60 \\
\mathrm{n}=235\end{array}$ & 4 & 15.4 & 231 & 49.8 & \\
\hline \multirow[t]{2}{*}{ Gender } & $\begin{array}{l}\text { Males } \\
\mathrm{n}=204\end{array}$ & 15 & 57.7 & 189 & 40.7 & \multirow{2}{*}{0.1} \\
\hline & $\begin{array}{c}\text { Females } \\
\mathrm{n}=286\end{array}$ & 11 & 42.3 & 275 & 59.3 & \\
\hline \multirow[t]{2}{*}{ Weather } & $\begin{array}{c}\text { Warm seasons } \\
\mathrm{n}=219\end{array}$ & 18 & 69.2 & 201 & 43.3 & \multirow{2}{*}{$0.01^{*}$} \\
\hline & $\begin{array}{l}\text { Cold seasons } \\
\mathrm{n}=271\end{array}$ & 8 & 30.8 & 263 & 56.7 & \\
\hline
\end{tabular}

*Significant $P$ value.

Table 3. Distinctive clinical features of patients infected with Shigella as a cause of diarrhea.

\begin{tabular}{|c|c|c|c|c|c|}
\hline & \multicolumn{2}{|c|}{$\begin{array}{l}\text { Patients with diarrhea } \\
\text { positive results for Shigella } \\
\qquad(\mathrm{n}=26)\end{array}$} & \multicolumn{2}{|c|}{$\begin{array}{l}\text { Patients with diarrhea } \\
\text { negative results for Shigella } \\
\qquad(\mathrm{n}=464)\end{array}$} & \multirow[t]{2}{*}{$P$ value } \\
\hline & No & $\%$ & No & $\%$ & \\
\hline Dehydration & 7 & 26.9 & 126 & 27.2 & 0.8 \\
\hline Blood in stool & 8 & 30.8 & 78 & 16.8 & 0.1 \\
\hline Presence of fever & 17 & 65.4 & 201 & 43.3 & $0.04^{*}$ \\
\hline Vomiting & 14 & 53.8 & 316 & 68.1 & 0.1 \\
\hline Hospital admission & 2 & 7.7 & 43 & 9.3 & 0.9 \\
\hline Abdominal pain & 5 & 19.2 & 172 & 37.1 & 0.1 \\
\hline Convulsion episodes & 1 & 3.8 & 13 & 2.8 & 0.7 \\
\hline
\end{tabular}

*Significant $P$ value. 
antibiotic sensitivity testing. The isolates recorded also good sensitivity for amikacin $(96.2 \%)$ and showed a sensitivity of $92.3 \%$ for ceftazidime, ceftriaxone and cefepime. Nalidixic acid and co-trimoxazole were the least effective antibiotics against the examined Shigella isolates as they recorded a sensitivity of $11.5 \%$ and $19.2 \%$ respectively (Table 4). Resistance to unrelated three or more classes of antibiotics was observed in 19 isolates, accounted for $73.1 \%$ of all studied Shigella and considered to be MDR isolates (11 were S. flexneri, 5 were $S$. sonnei, 2 were $S$. dysenteriae and 1 was $S$. boydii).

Fifteen isolates among the 19 MDR Shigella (78.9\%) were found to harbor in$t I 1$ gene as proved by PCR assay. intI1 gene was most frequently detected in $S$. flexneri (11 isolates) followed by $S$. sonnei (3 isolates) and $S$. boydii (1 isolate).

Muliplex PCR revealed that 18 isolates of the 19 MDR Shigella (94.7\%) were found to be positive for ipa $H$ and ipaBCD, 15 isolates (78.9\%) were proved to be positive for virA gene. sat gene was explored in 14 isolates (73.7\%), 10 of 11 (90.9\%) S. flexneri, two S. dysenteriae (100\%), one S. boydii (100\%) and 1 of 5 (20\%) S. sonnei. ial gene was found to be harbored by 13 isolates $(68.4 \%)$ of the studied MDR Shigella, it was found in 9 of $11(81.8 \%)$ S. flexneri, 3 of $5(60 \%)$ S.sonnei and 1 of $2(50 \%) S$. dysenteriae. set $1 A$ and set $1 B$ were found to be present in 8 isolates $(42.1 \%)$, all of them were $S$. flexneri. sen gene was detected in 7 isolates (36.8\%), 3 of 11 (27.3\%) S. flexneri, 2 of 5 (40\%) S. sonnei and two $S$. dysenteriae (100\%). None of the examined MDR Shigella isolates exhibited presence of stx gene by the multiplex PCR assay.

\section{Discussion}

Shigella infection as a cause of diarrheal illness remains an important dilemma in

Table 4. The pattern of antimicrobial susceptibility testing of Shigella isolates.

\begin{tabular}{ccccc}
\hline & \multicolumn{4}{c}{ The studied Shigella isolates $(\mathbf{n}=26)$} \\
\cline { 2 - 5 } & \multicolumn{2}{c}{ Sensitive } & Resistant \\
\cline { 2 - 5 } & No & $\%$ & 17 & $\%$ \\
\hline Ampicillin & 9 & 34.6 & 21 & 65.4 \\
Co-trimoxazole & 5 & 19.2 & 2 & 80.8 \\
Ceftazidime & 24 & 92.3 & 6 & 7.7 \\
Cefotaxime & 20 & 76.9 & 23 & 88.5 \\
Nalidixic acid & 3 & 11.5 & 2 & 7.7 \\
Ceftriaxone & 24 & 92.3 & 7 & 26.9 \\
Ciprofloxacin & 19 & 73.1 & 0 & 0 \\
Imipenem & 26 & 100 & 1 & 3.8 \\
Amikacin & 25 & 96.2 & 8 & 30.8 \\
Gentamicin & 18 & 69.2 & 11 & 42.3 \\
Chloramphenicol & 15 & 57.7 & 2 & 7.7 \\
Cefepime & 24 & 92.3 & &
\end{tabular}


developing communities, also it has been listed among the most frequent bacterial infections associated with enteric illness in developed countries [32].

Egyptian studies regarding Shigella are limited; epidemiology and serotyping were the most important aims of previous researches that had been conducted on Egyptian patients, particularly children [33] [34] [35]. Isolation of MDR Shigella from pediatric patients with diarrheal illness and its association with movable genetic elements (class 1 integrase) and other virulence genes were the main objectives of the present study.

The present study revealed a prevalence rate of 5.3\% for Shigella as a causative agent of diarrhea in children, approximating that previously reported by Lluque et al., 2015 [26], who could isolate Shigella from (69/1235) stool samples of children with diarrheal illness, recording 5.6\% isolation rate. Shigella prevalence among Indian children documented a value of $6 \%$ versus $1 \%$ in adult which is parallel to the present results [13]. A lower isolation rate was observed in other study performed in Turkey; the authors reported that Shigella had been detected only in $1.6 \%$ of the studied pediatric cases suffering from diarrhea [7]. Recent study achieved in Iran showed higher percentage of Shigella species in diarrheal samples of the examined children (75/946, 7.9\%) [27].

Previous researches conducted on patients suffering from diarrhea documented higher rate of Shigella isolation among children than adult patients; Antoine et al., 2010 [18] performed their study on patients with different ages and they observed a prevalence rate of $2.6 \%$ for all patients, however; $5.1 \%$ was the documented prevalence among children under the age of five in their research. Children over the age of five were found to be more affected than children under the age of five as reported by Ghosh et al., 2011 [36] (69\% and 31\% respectively).

The present study showed that $57.7 \%$ of Shigella isolates were from children in the second year of life which was in agreement with the previous Egyptian study that reported diarrhea related Shigella incidence with higher frequency in children after the age of six month reaching its peak at the age of two years [33]. The difference in Shigella prevalence among different studies usually reflects the variation in health care levels among various localities; however the common finding was the children higher prevalence that supports choice of children as the studied age group in the present research.

More than half of the isolated Shigella (57.7\%) in the present study was $S$. flexneri species, supporting the previous finding of Abu-Elyazeed et al., 2004, in their Egyptian study [33]; they reported $S$. flexneri as the most common species (55\%) of Shigella isolated from diarrheal samples of pediatric patients; Antoine et al., 2010, also found that $S$. flexneri accounted for $52.8 \%$ of the isolated Shigella [18]; similarly, Barrantes et al., 2014, observed that $S$. flexneri represented $83 \%$ of the isolated Shigella [2]. On the other hand, S. sonnei was found to be the most prevalent Shigella species in other studies [7] [37] [27] reflecting the various species distribution in different localities.

The present study reported fever and vomiting as the most common clinical 
presentations of children with Shigella associated diarrhea supporting the fact of high invasive capacity of this organism; this finding was in parallel with that previously reported in Egyptian studies [33] [34] and the Turkish study conducted by Özmert et al., 2011 [7]. Other studies mentioned that bloody stool was the commonest presentation of children with Shigella associated diarrheal illness [13], reflecting the difference in the expression of several virulence factors of Shigella among various localities.

The examined Shigella isolates exhibited an elevated rate of resistance to most of the examined antibiotics. Previous reports documented the progressive increased resistance of Shigella to several antimicrobials leading to adverse outcomes [38]. The initial antibiotic therapy for Shigella infections is dependant mainly on ampicillin and co-trimoxazole [39], however the current study reported an elevated resistance for both antibiotics, $65.4 \%$ and $80.8 \%$ respectively which limits the therapeutic options, this was in agreement with previous researches that recorded high resistance to co-trimoxazole up to $96.5 \%$ [40] [41] [42].

Nalidixic acid recorded the highest rate of resistance for the examined isolates, $88.5 \%$, which is in concurrence with previous data [43] [44], however a lower resistance rate was recorded in other studies (34.4\%) [37]. The recorded percentage of ciprofloxacin resistance for the examined isolates $(26.9 \%)$ reflects the possibility of emergence of quinolone resistance strains among Shigella which is in need for further analysis as it is considered to be alike finding in many studies [45] [46]. Imipenem remains the mostly efficient antibiotic against all of the isolates ( $100 \%$ sensitivity rate) putting it in the first position of treatment options of the isolated Shigella strains in the present study and it could be used as an alternative to amikacin (96.2\% sensitivity) avoiding its unwanted side effects. The emergence and spread of clones resistant to antibiotics in different localities could clarify the various antimicrobial profiles of Shigella isolates that are mainly influenced by the pressure related to antibiotic usage.

Shigella isolates in the present work generally exhibited an elevated degree of antibiotic resistance as $73.1 \%$ of them were classified as MDR, preceding studies demonstrated higher antibiotic resistance rate than that currently recorded, $87 \%$, 90\%, 95.6\%, 97.9\% were the percentages of MDR Shigella isolates reported by previous researchers [2] [36] [47] [48], however, MDR Shigella isolates recorded a percentage of $70 \%$ that approximating our results by Sangeetha et al., 2014 [13]. Generally, gaining of MDR criteria by Shigella species seems to be an important observation that should draws the attention as this may be a dangerous obstacle in patient management.

The wide dissemination of Shigella resistance is very important. It is usually mediated by movable determinant like integrons [14]. In the present study, intI1 gene was found to be harbored by $78.9 \%$ of the MDR Shigella isolates approximating the prevalence that has been recorded by Zhu et al., 2011 [47] (79.1\%), however this percentage seems to be low in relation to other studies. Frank et al., 
2007 [17] observed the presence of intI1 gene in $88.8 \%$ of Shigella isolates, Yang et al., 2014 [24] recorded the presence of that gene in $90.3 \%$ of the examined MDR Shigella, in the same year, Barrantes et al., 2014 [2], also observed an elevated prevalence of intII gene among Shigella species (93\%). The increasing prevalence of integrase gene in Shigella isolates is a reflection of the high possibility of further spread of resistance species. In other localities with different pattern of bacterial resistance and antibiotic policies, a lower prevalence of intII gene has been recorded, $44.2 \%$ of Shigella isolates were found to be positive for intI1 gene in an Indian study [48].

Virulence genes detection in the MDR Shigella is very important as they could be strongly associated with the resistance profile of those isolates. In the present research, testing of the MDR Shigella by the multiplex PCR assay revealed presence of $i p a H$ and $i p a B C D$ in most of the examined isolates (94.7\%) which was in agreement with previous studies, Antoine et al., 2010 [18] reported the presence $i p a H$ in $90.2 \%$ of Shigella isolates. Other authors confirmed the occurrence of that gene in all of their tested Shigella strains [13] [27] [49] [50] [51]. In harmony with our results, $i p a B C D$ was found to be harbored by all Shigella isolates that were previously examined [52] [53]. ipa $H$ gene is a constant gene that it is expressed with many copies on chromosomes and plasmids giving an explanation for its existence in all Shigella isolates [18]. virA gene was found to be expressed by $78.9 \%$ of MDR Shigella isolates approximating results that has been previously reported [36]. Recently, Yaghoubia et al., 2017 [27] recorded the presence of this gene in all Shigella isolates confirming its essential role in the cellular invasion. Regarding sat gene, it was initially reported in E.coli (uropathogenic strains). Recently, Shigella isolates were found to express that gene [20]. In a recent study conducted in 2017 [27], sat gene was only expressed in 28\% of Shigella which is much lower than the gene percentage revealed in the present study (73.7\%).

The gene $i a l$ is less stable being expressed mainly on inv plasmid; it may be exposed to deletion [54]; its percentage in the present work was $68.4 \%$ which is much lower than ipaHgene. In previous study performed in 2010 the prevalence of this gene was low (46.3\%) [18]. However, the present results was in harmony with that recently reported in 2017 as $74.7 \%$ of the studied Shigella isolates were found to be positive for that gene [27], meaning that the capacity of Shigella to be more virulent as regarding cellular spread has been increased. $S$. flexneri isolates were the only species in the present study that found to be positive for set $1 A$ and set $1 B$ genes, which are tandem genes being expressed by the same isolates [13]. The same observation was recorded by recent research performed in 2016 [55], this gene confirmed a prevalence of 7\% in a previously performed study [52] which was much lower than that observed in the present work.

The sen gene which is specific for enterotoxin 2 production was found to be expressed only by $36.8 \%$ of the MDR isolates approximating the preceding results documented by Casabonne et al., 2016 [52] (40\%) and Yaghoubia et al., 
2017 [27] (45.4\%), higher prevalence of that gene was observed in other studies; as Hosseini et al., 2015 [55] and Ghosh et al., 2011 [36], confirmed its presence in $66.1 \%$ and $91.5 \%$ of the tested Shigella isolates respectively. Fortunately all of the examined isolates were found to be negaive for stx gene, being the gene associated with serious complications of Shigella related diarrhea, these results matched the previously recorded data [13]. On the other hand $S$. dysenteriae and S. flexneri isolates were respectively found to be positive for this gene as proved in previous researches [27] [56], higher percentage of different Shigella species (21\%) were proved to be positive for that gene in French study conducted in 2015 [57] as all of the examined patients were travellers who had been returned from other locality.

The current study was limited by the low number of the examined Shigella isolates as detection of class 1 integrase and other virulence genes was restricted only for the MDR species. Further studies are recommended to detect other resistant determinants in Shigella isolated from patients with different age groups which is very important to form a clear idea about the resistance profile of Shigella in Egyptian patients.

\section{Conclusion}

In the present study, Shigella has been accounted for $5.3 \%$ of pediatric cases with diarrheal illness. Although this prevalence seems to be low, more than two thirds (73.1\%) of those isolates were proved to be MDR. The presence of intI1 gene was documented in $78.9 \%$ of the MDR Shigella meaning that the probability of resistant species dissemination is considered. Virulence genes of various types were detected in the examined MDR isolates with substantial values reflecting the strong association between MDR criteria and presence of virulence genes which in no doubt affects the disease outcome, particularly in children.

\section{Conflicts of Interest}

The authors declare no conflicts of interest regarding the publication of this paper.

\section{References}

[1] Rolfo, F., Marin, G.H., Silberman, M., Pattin, J., Giugnio, S., Gatti, B., Bettiol, M. and Rigoni, A. (2012) Epidemiological Study of Shigellosis in an Urban Area of Argentina. Journal of Infection in Developing Countries, 6, 324-328.

[2] Barrantes, K., Chacon, L., Solano, M. and Achi, R. (2014) Class 1 Integrase and Genetic Cassettes bla $_{\text {oxa }}$ and bla $_{\text {tem }}$ among Multi-Drug Resistant Shigella Isolates in Costa Rica. International Journal of Biological Sciences, 1, 24-27

[3] Peirano, G., Souza, F.S. and Rodrigues, D.P. (2006) Frequency of Serovars and Antimicrobial Resistance in Shigella spp. from Brazil. Memórias do Instituto Oswaldo Cruz, 101, 245-250. https://doi.org/10.1590/S0074-02762006000300003

[4] Peng, J., Yang, J. and Jin, Q. (2009) The Molecular Evolutionary History of Shigella spp. and Enteroinvasive Escherichia coli. Infection, Genetics and Evolution, 9, 
147-152. https://doi.org/10.1016/j.meegid.2008.10.003

[5] Taneja, N., Khurana, S., Verma, A.D. and Sharma, M. (2003) Changing trands in shigellosis at a Tertiary Care Center. Indian Journal of Pathology and Microbiology, 46, 280-281.

[6] Emch, M., Ali, M. and Yunus, M. (2008) Risk Areas and Neighborhood-Level Risk Factors for Shigella dysenteriae 1 and Shigella flexneri. Health \& Place, 14, 96-105. https://doi.org/10.1016/j.healthplace.2007.05.004

[7] Ozmert, E.N., Ince, O.T., Orun, E., Yalc,1n, S., Yurdakok, K. and Gur, D. (2011) Clinical Characteristics and Antibiotic Resistance of Shigella Gastroenteritis in Ankara, Turkey between 2003 and 2009, and Comparison with Previous Reports. The International Journal of Infectious Diseases, 15, e849-e853. https://doi.org/10.1016/j.ijid.2011.08.008

[8] Traa, B.S., Walker, C.L., Munos, M. and Black, R.E. (2010) Antibiotics for the Treatment of Dysentery in Children. International Journal of Epidemiology, 39, i70-i74. https://doi.org/10.1093/ije/dyq024

[9] Leibovitz, E. (2006) The Use of Fluoroquinolones in Children. Current Opinion in Pediatrics, 18, 64-70.

[10] Jain, S.K., Gupta, A., Glanz, B., Dick, J. and Siberry, G.K. (2005) Antimicrobial-Resistant Shigella sonnei: Limited Antimicrobial Treatment Options for Children and Challenges of Interpreting in Vitro Azithromycin Susceptibility. The Pediatric Infectious Disease Journal, 24, 494-497. https://doi.org/10.1097/01.inf.0000164707.13624.a7

[11] World Health Organization (1989) The Treatment and Prevention of Acute Diarrhoea: Practical Guidelines. WHO, Geneva.

[12] Juyal, D., Negi, V., Sharma, M. and Sharma, N. (2013) Multi Drug Resistant Shigella flexneri-An Emerging Threat to Community. Journal of Pharmaceutical Research and Clinical Practice, 3, 29-33.

[13] Sangeetha, A.V., Parija, S.C., Mandal, J. and Krishnamurthy, S. (2014) Clinical and Microbiological Profiles of Shigellosis in Children. Journal of Health, Population and Nutrition, 32, 580-586.

[14] Ke, X., Gu, B., Pan, S. and Tong, M. (2011) Epidemiology and Molecular Mechanism of Integron-Mediated Antibiotic Resistance in Shigella. Archives of Microbiology, 193, 767-774. https://doi.org/10.1007/s00203-011-0744-3

[15] Mazel, D. (2006) Integrons: Agents of Bacterial Evolution. Nature Reviews Microbiology, 4, 608-620. https://doi.org/10.1038/nrmicro1462

[16] Poirel, L., Naas, T. and Nordmann, P. (2010) Diversity, Epidemiology, and Genetics of Class D (Beta)-Lactamases. Antimicrobial Agents and Chemotherapy, 54, 24-38. https://doi.org/10.1128/AAC.01512-08

[17] Frank, T., Gautier, V., Talarmin, A., Bercion, R. and Arlet, G. (2007) Characterization of Sulphonamide Resistance Genes and Class 1 Integron Gene Cassettes in Enterobacteriacea, Central African Republic (CAR). Antimicrobial Agents and Chemotherapy, 59, 742-745. https://doi.org/10.1093/jac/dkl538

[18] Antoine, B., Adjehi, D., Nathalie, G., Valerie, G., Etienne, D., Marcellin, D. and Mireille, D. (2010) Virulence Factors and Resistance Profile of Shigella Isolated During Infectious Diarrhea in Abidjan, Côte D'Ivoire. Journal of Applied Sciences Research, 6, 594-599.

[19] Parsot, C. (2005) Shigella spp. and Enteroinvasive Escherichia coli Pathogenicity Factors. FEMS Microbiology Letters, 252, 11-18. 
https://doi.org/10.1016/j.femsle.2005.08.046

[20] Schroeder, G.N. and Hilbi, H. (2008) Molecular Pathogenesis of Shigella spp.: Controlling Host Cell Signaling, Invasion, and Death by Type III Secretion. Clinical Microbiology Reviews, 21, 134-156. https://doi.org/10.1128/CMR.00032-07

[21] Unkmeir, A. and Schmidt, H. (2000) Structural Analysis of Phage-Borne STX Genes and Their Flanking Sequences in Shiga Toxin-Producing Escherichia coli and Shigella dysenteriae type 1 Strains. Infection and Immunity, 68, 4856-4864. https://doi.org/10.1128/IAI.68.9.4856-4864.2000

[22] Cherla, R.P., Lee, S.Y. and Tesh, V.L. (2003) Shiga Toxins and Apoptosis. FEMS Microbiology Letters, 228, 159-166. https://doi.org/10.1016/S0378-1097(03)00761-4

[23] Ranjbar, R., Soltan Dallal, M.M., Pourshafie, M.R., Aslani, M.M., Majdzadeh, R. and Khorramizadeh, M.R. (2004) Serogroup Distribution of Shigella in Tehran. Iranian Journal of Public Health, 33, 32-35.

[24] Yang, H., Pan, Y., Hu, L., Liu, Y., Ye, Y., Cheng, J. and Li, J. (2014) Antimicrobial Resistance Patterns and Characterization of Integrons in Clinical Isolates of Shigella from China. Canadian Journal of Microbiology, 60, 237-242.

https://doi.org/10.1139/cjm-2013-0893

[25] Clinical and Laboratory Standards Institute (CLSI) (2014) Performance Standards for Antimicrobial Susceptibility Testing; Twenty-Fourth Informational Supplement M100-S24. CLSI, Wayne, PA.

[26] Lluque, A., Mosquito, S., Gomes, C., Riveros, M., Durand, D., Tilley, D.H., Bernal, M., Prada, A., Ochoa, T.J. and Ruiz, J. (2015) Virulence Factors and Mechanisms of Antimicrobial Resistance in Shigella Strains from Periurban Areas of Lima (Peru). International Journal of Medical Microbiology, 305, 480-490. https://doi.org/10.1016/j.ijmm.2015.04.005

[27] Yaghoubia, S., Ranjbarb, R., Dallala, M.M.S., Fardd, S.Y., Shirazia, M.H. and Mahmoudie, M. (2017) Profiling of Virulence-Associated Factors in Shigella Species Isolated from Acute Pediatric Diarrheal Samples in Tehran, Iran. Osong Public Health and Research Perspectives, 8, 220-226.

https://doi.org/10.24171/j.phrp.2017.8.3.09

[28] Vargas, M., Gascon, J., Jimenez De Anta, M.T. and Vila, J. (1999) Prevalence of Shigella Enterotoxins 1 and 2 among Shigella Strains Isolated from Patients with Traveler's Diarrhea. Journal of Clinical Microbiology, 37, 3608-3611.

[29] Ruiz, J., Navia, M.M., Vila, J. and Gascon, J. (2002) Prevalence of the Sat Gene among Clinical Isolates of Shigella spp. Causing Travelers' Diarrhea: Geographical and Specific Differences. Journal of Clinical Microbiology, 40, 1565-1566. https://doi.org/10.1128/JCM.40.4.1565-1566.2002

[30] Faruque, S.M., Khan, R., Kamruzzaman, M., Yamasaki, S., Ahmad, Q.S., Azim, T., Nair, G.B., Takeda, Y. and Sack, D.A. (2002) Isolation of Shigella Dysenteriae Type 1 and S. Flexneri Strains from Surface Waters in Bangladesh: Comparative Molecular Analysis of Environmental Shigella Isolates versus Clinical Strains. Applied and Environmental Microbiology, 68, 3908-3913. https://doi.org/10.1128/AEM.68.8.3908-3913.2002

[31] Zhang, C.L., Liu, Q.Z., Wang, J., Chu, X., Shen, L.M. and Guo, Y.Y. (2014) Epidemic and Virulence Characteristic of Shigella spp. with Extended-Spectrum Cephalosporin Resistance in Xiaoshan District, Hangzhou, China. BMC Infectious Diseases, 14, 260. https://doi.org/10.1186/1471-2334-14-260

[32] Wong, M.R., Reddy, V., Hanson, H., Johnson, K.M., Tsoi, B., Cokes, C., Gallagher, L., Lee, L., Plentsova, A., Dang, T., Krueger, A., Joyce, K. and Balter, S. (2010) An- 
timicrobial Resistance Trends of Shigella Serotypes in New York City, 2006-2009. Microbial Drug Resistance, 16, 155-161. https://doi.org/10.1089/mdr.2009.0130

[33] Abu-Elyazeed, R.R., Wierzba, T.F., Frenck, R.W., Putnam, S.D., Rao, M.R., Savarino, S.J., Kamal, K.A., Peruski Jr., L.F., Abd-El Messih, I.A., El-Alkamy, S.A., Naficy, A.B. and Clemens, J.D. (2004) Epidemiology of Shigella-Associated Diarrhea in Rural Egyptian Children. The American Journal of Tropical Medicine and Hygiene, 71, 367-372. https://doi.org/10.4269/ajtmh.2004.71.367

[34] El-Gendy, A.M., Mansour, A., Weiner, M.A., Pimentel, G., Armstrong, A.W., Young, S.Y., Elsayed, N. and Klena, J.D. (2012) Genetic Diversity and Antibiotic Resistance in Shigella dysenteriae and Shigella boydii Strains Isolated from Children Aged < 5 Years in Egypt. Epidemiology \& Infection, 140, 299-310.

https://doi.org/10.1017/S0950268811000525

[35] Dejli, J., Nada, R.A., Mansour, A., El-Moniem, A.A., Wasfy, M.O. and Klena, J.D. (2013) Comparative Analysis of Shigella sonnei Biotype G Isolated from Paediatric Populations in Egypt, 1999-2005. Epidemiology \& Infection, 141, 1614-1624. https://doi.org/10.1017/S0950268812002002

[36] Ghosh, S., Pazhani, G.P., Chowdhury, G., Guin, S., Dutta, S., Rajendran, K., Bhattacharya, M.K., Takeda, Y., Niyogi, S.K., Nair, G.B. and Ramamurthy, T. (2011) Genetic Characteristics and Changing Antimicrobial Resistance among Shigella spp. Isolated from Hospitalized Diarrhoeal Patients in Kolkata, India. Journal of Medical Microbiology, 60, 1460-1466. https://doi.org/10.1099/jmm.0.032920-0

[37] Mardaneh, J., Poor, S.A. and Afrugh, P. (2013) Prevalence of Shigella Species and Antimicrobial Resistance Patterns of Isolated Strains from Infected Pediatrics in Tehran. International Journal of Enteric Pathogens, 1, e10705. https://doi.org/10.17795/ijep10705

[38] Niyogi, S.K. (2005) Shigellosis. Journal of Microbiology, 43, 133-143.

[39] Chang, C.Y., Lu, P.L., Lin, C.C., Lee, T.M., Tsai, M.Y. and Chang, L. (2011) Integron Types, Gene Cassettes, Antimicrobial Resistance Genes and Plasmids of Shigella sonnei Isolates from Outbreaks and Sporadic Cases in Taiwan. Journal of Medical Microbiology, 60, 197-204. https://doi.org/10.1099/jmm.0.022517-0

[40] Abu Elamreen, F.H., Sharif, F.A. and Deeb, J.E. (2008) Isolation and Antibiotic Susceptibility of Salmonella and Shigella Strains Isolated from Children in Gaza, Palestine from 1999 to 2006. Journal of Gastroenterology and Hepatology, 23, 330-333. https://doi.org/10.1111/j.1440-1746.2007.05139.x

[41] Khan, E., Jabeen, K., Ejaz, M., Siddiqui, J., Shezad, M.F. and Zafar, A. (2009) Trends in Antimicrobial Resistance in Shigella Species in Karachi, Pakistan. The Journal of Infection in Developing Countries, 3, 198-202.

[42] Jafari, F., Hamidian, M., Rezadehbashi, M., Doyle, M., Salmanzadeh-Ahrabi, S., Derakhshan, F. and Reza Zali, M. (2009) Prevalence and Antimicrobial Resistance of Diarrheagenic Escherichia coli and Shigella Species Associated with Acute Diarrhea in Tehran, Iran. Canadian Journal of Infectious Diseases and Medical Microbiology, 20, 56-62. https://doi.org/10.1155/2009/341275

[43] Hirose, K., Terajima, J., Izumiya, H., Tamura, K., Arakawa E., Takai, N. and Watanabe, H. (2005) Antimicrobial Susceptibility of Shigella sonnei Isolates in Japan and Molecular Analysis of S. sonnei Isolates with Reduced Susceptibility to Fluoroquinolones. Antimicrobial Agents and Chemotherapy, 49, 1203-1205. https://doi.org/10.1128/AAC.49.3.1203-1205.2005

[44] Pazhani, G.P., Niyogi, S.K., Singh, A.K., Sen, B., Taneja, N., Kundu, M., Yamasaki, S. and Ramamurthy, T. (2008) Molecular Characterization of Multidrug-Resistant 
Shigella Species Isolated from Epidemic and Endemic Cases of Shigellosis in India. Journal of Medical Microbiology, 57, 856-863. https://doi.org/10.1099/jmm.0.2008/000521-0

[45] Mamishi, S., Mashoori, N., Mahboobi, N. and Pour Akbari, B. (2009) Increasing Resistance to Nalidixic Acid in Shigella Subgroups in a Comparative Study between 2001-2003 and 2004-2006. Singapore Medical Journal, 50, 791-793.

[46] Pons, M.J., Gomes, C., Martínez-Puchol, S., Ruiz, L., Mensa, L., Vila, J., Gascón, J. and Ruiz, J. (2013) Antimicrobial Resistance in Shigella spp. Causing Traveller's Diarrhoea (1995-2010): A Retrospective Analysis. Travel Medicine and Infectious Disease, 11, 315-319. https://doi.org/10.1016/j.tmaid.2013.06.010

[47] Zhu, J., Duan, G., Yang, H., Fan, Q. and Xi, Y. (2011) Multi-Drug Resistance and Characteristic of Integrons in Shigella spp. Isolated from China. Biomedical and Environmental Sciences, 24, 56-61.

[48] Rajpara, N., Nair, M., Chowdhury, G., Mukhopadhyay, A.K., Ramamurthy, T., Niyogi, S.K. and Bhardwaj, A.K. (2018) Molecular Analysis of Multidrug Resistance in Clinical Isolates of Shigella spp. from 2001-2010 in Kolkata, India: Role of Integrons, Plasmids, and Topoisomerase Mutations. Infection and Drug Resistance, 11, 87-102. https://doi.org/10.2147/IDR.S148726

[49] Vu, D.T., Sethabutr, O., Von Seidlein, L., Tung, T.V., Canh, D.G., Chien, B.T., Tho, L.H., Lee, H., Houng, H.S., Hale, T.L., Clemens, J.D., Mason, C. and Trach, D.D. (2004) Detection of Shigella by a PCR Assay Targeting the ipaH Gene Suggests Increased Prevalence of Shigellosis in Nha Trang, Vietnam. Journal of Clinical Microbiology, 42, 2031-2035. https://doi.org/10.1128/JCM.42.5.2031-2035.2004

[50] Binet, R., Deer, D.M. and Uhlfelder, S.J. (2014) Rapid Detection of Shigella and Enteroinvasive Escherichia coli in Produce Enrichments by a Conventional Multiplex PCR Assay. Food Microbiology, 40, 48-54. https://doi.org/10.1016/j.fm.2013.12.001

[51] Farshad, S., Ranjbar, R. and Hosseini, M. (2014) Molecular Genotyping of Shigella Sonnei Strains Isolated from Children with Bloody Diarrhea Using Pulsed Field Gel Electrophoresis on the Total Genome and PCR-RFLP of IpaH and IpaBCD Genes. Jundishapur Journal of Microbiology, 8, e14004. https://doi.org/10.5812/jim.14004

[52] Casabonne, C., González, A., Aquili, V. and Balagué, C. (2016) Prevalence and Virulence Genes of Shigella spp. Isolated from Patients with Diarrhea in Rosario, Argentina. Japanese Journal of Infectious Diseases, 69, 477-481.

[53] Cruz, C.B.N., Souza, M.C.S., Serra, P.T., Santos, I., Balieiro, A., Pieri, F.A., Nogueira, P.A. and Orlandi, P.P. (2014) Virulence Factors Associated with Pediatric Shigellosis in Brazilian Amazon. BioMed Research International, 2014, Article ID: 539697. https://doi.org/10.1155/2014/539697

[54] Thong, K.L., Hoe, S.L.L., Puthucheary, S.D. and Ysin, R.M. (2005) Detection of Virulence Genes in Malaysian Shigella Species by Multiplex Assay. BMC Infectious Diseases, 5, 8. https://doi.org/10.1186/1471-2334-5-8

[55] Hosseini Nave, H., Mansouri, S., Emaneini, M. and Moradi, M. (2016) Distribution of Genes Encoding Virulence Factors and Molecular Analysis of Shigella spp. Isolated from Patients with Diarrhea in Kerman, Iran. Microbial Pathogenesis, 92, 68-71. https://doi.org/10.1016/j.micpath.2015.11.015

[56] Bekal, S., Pilon, P.A., Cloutier, N., Doualla-Bell, F. and Longtin, J. (2015) Identification of Shigella Flexneri Isolates Carrying the Shiga Toxin 1-Producing Gene in Quebec, Canada, Linked to Travel to Haiti. Canadian Journal of Microbiology, 61, 995-996. https://doi.org/10.1139/cjm-2015-0538

[57] Gray, M.D., Lacher, D.W., Leonard, S.R., Abbott, J., Zhao, S., Lampel, K.A., Pro- 
thery, E., Gouali, M., Weill, F.X. and Maurelli, A.T. (2015) Prevalence of Shiga Toxin-Producing Shigella Species Isolated from French Travellers Returning from the Caribbean: An Emerging Pathogen with International Implications. Clinical Microbiology and Infection, 21, 765.e9-765.e14.

https://doi.org/10.1016/j.cmi.2015.05.006 